\title{
CORRIGENDUM
}

\section{Differential subsidence in the urbanised coastal-deltaic plain of the Netherlands - CORRIGENDUM}

\section{Kay Koster, Jan Stafleu \& Esther Stouthamer}

Keywords: 3D modelling, compression, Holocene peat, oxidation, water management, CORRIGENDUM

https://doi.org/10.1017/njg.2018.11. Published by Cambridge University Press 09 0ctober 2018

An error has occurred in Table 1 of this article (Koster, K; Stafleu, J; Stouthamer, E). The correct Table 1 is given below.

Table 1. Overview of the four phreatic groundwater level lowering scenarios.

\begin{tabular}{lll}
\hline Scenario & Duration $(\mathbf{y r})$ & Phreatic groundwater level lowering $(\mathbf{m})$ \\
\hline 1 & 15 & 0.25 \\
2 & 30 & 0.25 \\
3 & 15 & 0.5 \\
4 & 30 & 0.5 \\
\hline
\end{tabular}

\section{Reference}

Koster, K., Stafleu, J., \& Stouthamer, E. (n.d.). Differential subsidence in the urbanised coastal-deltaic plain of the Netherlands. Netherlands Journal of Geosciences, 1-13. doi:10.1017/njg.2018.11 